\title{
СПІЛЬНОТА В УМОВАХ ВОСННОГО КОНФЛІКТУ: ТЕОРЕТИЧНІ ЗАСАДИ ДОСЛІДЖЕННЯ ПСИХОЛОГІЧНИХ СТРАТЕГІЙ АДАПТАЦІї
}

Обгрунтовано теоретичні засади дослідження психологічних стратегій адаптації спільноти до умов і наслідків воєнного конфлікту, основу яких становлять концепція соціальної травми П. Штомпки та загальні положення про спільноту як структурну одиницю суспільства i значущого середовища життєдіяльності особи, адаптацію особи та спільноти в умовах суспільних трансформацій, адаптацію як вибір альтернативних стратегій поведінки. Адаптацію спільноти до умов і наслідків воєнного конфлікту розглянуто як складний багатомірний процес взаємодії суб' єкта адаптації і середовища, яке змінюється під впливом воєнного конфлікту, що передбачає трансформацію системних властивостей спільноти, набуття нових засобів побудови продуктивних систем взаємодії, вироблення і застосування відповідних психологічних стратегій оволодіння ситуацією. Визначено суб' єктивні критерії адаптації (задоволеність соціальним оточенням, роллю, статусом, рівнем самореалізації, основними видами діяльності, реалізацією основних потреб; відчуття соціальної інтегрованості, самооцінка стану здоров’я та адаптивності) та їх значення в дослідженні стратегій адаптації спільноти до таких умов. Психологічні стратегії адаптації спільноти запропоновано розглянути на основі моделей: зміцнення громадського здоров'я, ціннісного порозуміння, розв'язання проблем внутрішньої міграції, опрацювання травматичного досвіду, застосування медіапрактик, родинної взаємодії, трансформації соціального капіталу. Відповідно до цих моделей визначено емпіричні індикатори дослідження психологічних стратегій адаптації спільноти до умов і наслідків воєнного конфлікту.

Ключові слова: спільнота, адаптація, умови воєнного конфлікту, критерії адаптації, психологічні стратегії адаптації, індикатори дослідження стратегій адаптації спільноти.

Проблема. Воєнний конфлікт та його наслідки впливають на різні сфери життєдіяльності людей, змушують їх неперервно й швидко адаптуватися до суспільних змін, спричинених цим конфліктом. Усе це вимагає нових підходів до проблеми адаптації як окремої особи, так і різних соціальних груп, спільнот та вироблення соціальнопсихологічних засобів активізації колективних зусиль із подолання негативних наслідків цих подій у різних сферах життєдіяльності. 
У сучасних психологічних дослідженнях проблемі адаптації особистості приділяється значна увага. Грунтовні дослідження присвячено вивченню психофізіологічної, психічної, психологічної, соціально-психологічної адаптації, захисних адаптивних механізмів та адаптивних характеристик особистості (Г. О. Балл, О.М.Кокун, М. С. Корольчук, А. Г. Маклаков, В. Ф. Моргун, А. А. Налчаджян, В. І. Розов, Т. С. Яценко); адаптації особи в умовах суспільних трансформацій, у складних життєвих ситуаціях (С. І. Головаха, О. А. Донченко, О. Г. Злобіна, В. О. Климчук, О. М. Лактіонов, Н. В. Паніна, Т. М. Титаренко); стратегій адаптації в складних ситуаціях, умовах та критеріїв їх визначення (О.В.Вітенберг, Р. Лазарус, В. В. Москаленко, О. Г. Посипанов, М. В. Ромм, Т. І. Ронгінська).

Західними дослідниками проблема адаптації людини представлена в контексті теорії адаптації i зараджувальної поведінки (M. Chaturvedi, S. Folkman, L. Kahle, R. Lazarus, R. H. Moos, J. A. Schaefer); позитивної психології, яка розглядає адаптацію особистості в складних життєвих ситуаціях як процес “позитивної адаптації” чи “посттравматичного зростання" (R. Tedeschi, L. Calhoun, S. Joseph, N. Pole, M. Seligman) тощо.

Цінним $є$ практичний досвід психологічної роботи з населенням у країнах, що переживають наслідки воєнного конфлікту (Ізраїль, Грузія). Він свідчить про необхідність працювати не тільки із самими постраждалими внаслідок війни, а й з їхніми родинами, спільнотами, 3 країною в цілому (М. Дорон, Д. Джавахішвілі, Н. Сарджвеладзе). Також суттєві напрацювання з надання психологічної допомоги мешканцям України в умовах воєнного конфлікту представлено науковцями Інституту соціальної та політичної психології НАПН України О. Л. Вознесенською, О. Ю. Осадько, О. Т. Плеткою, М. Ю. Сидоркіною, Т. М. Титаренко, Ю. С. Чаплінською, Г. В. Циганенко та ін.

Ситуація воєнного конфлікту на сході України, внаслідок якого відбувається посилення в суспільстві тривожних настроїв, страху, розчарування, розгубленості, дезадаптації, змістила акценти та змінила поле осягнення проблеми адаптації до умов і наслідків воєнного конфлікту, показала необхідність підвищення рівня індивідуальної та колективної адаптації до таких умов, вироблення ефективних психологічних стратегій адаптації, що й стало завданнями НДР лабораторії психології мас та спільнот на 2016-2018 роки. Перший етап НДР передбачав обгрунтування теоретико-методичних засад дослідження психологічних стратегій адаптації спільноти до умов і наслідків воєнного конфлікту.

Мета cmammi: на основі узагальнення і систематизації даних теоретичного та емпіричного вивчення проблеми обгрунтувати теоре- 
тико-методичні засади дослідження психологічних стратегій адаптації спільноти до умов і наслідків воєнного конфлікту.

В основу дослідження психологічних стратегій адаптації спільноти до умов і наслідків воєнного конфлікту покладено загальні положення концепції соціальної травми П. Штомпки, відповідно до яких негативні чинники травматичних подій, “катастрофи як ситуації” (до яких ми відносимо, зокрема, воєнний конфлікт) доцільно трактувати як симптоми соціальної травми, а характер їхнього впливу на життєдіяльність людей - як соціально травматичний. Проблемі колективної травми присвячені праці сучасних вітчизняних (П. П. Горностай, Н. В. Ходорівська) та зарубіжних (С. Carut, K. Erikson, K. Nader) учених.

Травму розглядають як колективний феномен, стан, що переживається групою, спільнотою, суспільством у результаті руйнівних подій, які інтерпретуються як культурно травматичні. Травма діє на колектив i, як стверджується в психоаналітичній літературі, не може бути індивідуальним порушенням [1, с. 10]. Травматичні зміни, пов’язані із ситуацією воєнного конфлікту на сході України, діють на різні компоненти соціуму неоднаково. На думку П. Штомпки, “...у кожної травми є центральні групи, які глибоко переживають і сприймають щі, та периферійні групи, для яких вона - неістотна, маргінальна ... Вплив тих самих потенційно травматичних подій (ситуацій) може бути якісно різним, навіть протилежним для різних груп” [там само, c. 13]. Вплив цих подій для одних деструктивний, руйнівний, для інших - корисний і бажаний, треті його ігнорують.

Унаслідок воєнного конфлікту та спричинених ним суспільних змін можна спостерігати увиразнення практично всіх симптомів колективної травми (за П. Штомпкою). Набувають поширення синдром недовіри, невіра в майбутнє, ностальгія за минулим, політична апатія, переоцінка минулого, аномія, цивілізаційна некомпетентність, соціальні тертя, колективне почуття провини, колективне почуття сорому, криза ідентичності, криза легітимності, зниження тривалості життя, зростання кількості самогубств, порушення каналів соціальних відносин, соціальної системи, ієрархї̈ тощо.

Результатом негативних процесів в Україні, пов'язаних із соціально-економічними проблемами, що виникли й зокрема внаслідок воєнного конфлікту, є перехід у стан депривації. Це явище в нашій країні, як показують соціологічні дослідження, переживається інакше, ніж в економічно розвинених державах. Така ситуація пов'язана з мобілізованою, живою пам'яттю про труднощі і втрати, що переживали люди, які живуть нині, адже досі існують та зберігаються сімейні істо- 
рії про ці труднощі. У нашій культурі феномен звикання пов'язаний із феноменом виживання, який тримається на традиції терпіння, адже соціальна маргіналізація, хаотизація життя в країні протягом багатьох років сформували специфічний стан звикання людей до такого способу життя [2, с. 15].

В умовах війни феномен виживання постає як специфічний спосіб життєдіяльності, що спирається на низькі життєві ресурси, необхідність забезпечити хоча б елементарне відтворення життя. У таких умовах людина організовує своє життя як очікування: воно спрощується, задоволення потреб, здійснення важливих учинків, дій відкладається на майбутнє, а всі форми активності спрямовані перш за все на самозбереження.

Таким чином, у ситуації воєнного конфлікту виживання стає способом організації життя (адаптації) в умовах досить обмежених ресурсів. Як зазначає М. О. Шульга, культурі наших людей притаманний складний комплекс “депривація-звикання-виживання”, що забезпечує відтворення суспільного життя в кризових умовах [там само, c. 18]. У цьому контексті можна говорити, що звикання є механізмом адаптації до нових умов та способу життя, натомість його зміст, наповнення та форми залежать від глибинних моделей культури, традицій та організації повсякденного життя людей.

Наразі спостерігаємо зростання активності громадян, різних спільнот у різних сферах соціального життя, адже криза $є$ не тільки “катастрофою”, а й певною можливістю. У кризових умовах, за наявності стимуляційних факторів, відбувається переструктуризація соціального організму, втрачаються старі та виникають нові можливості, що стимулює появу на арені соціального життя найбільш активних осіб, груп, спільнот, які готові до змін та їх впроваджують.

В основу нашого дослідження покладено розроблену В. О. Васютинським психологічну теорію спільноти. Вона визначається як відносно велика номінально-реальна соціальна група, що виділяється за наявністю спільної ознаки, яка є для багатьох або більшості ії носіїв суб' єктивно значущою [3, с. 18]. Вважаємо, що саме спільнота потребує особливої уваги в контексті підвищення ії адаптивного потенціалу як структурної одиниці і суспільства, і життєдіяльності особи в значущому для неї середовищі.

Важливими для нас також є сучасні напрацювання, пов'язані із суб'єктністю спільноти, iї здатністю до рефлексивності (Л. А. Найдьонова; М. І. Найдьонов) та відповідальністю (Т. П. Смельянова, К. Муздибаєв, L. Poleszak, P. Zylicz). Дослідники наголошують, що спільнота може виступати суб'єктом життєтворення, адже усвідомлює, рефлексує події та свідомо обирає стратегії адаптації, спрямовує коле- 
ктивні зусилля на підвищення рівня індивідуальної та колективної адаптації, подолання наслідків кризових і травматичних подій.

Значний інтерес становлять дослідження проблеми мобілізації потенціалу спільноти, коли йдеться про розв'язання соціальних проблем, успішність переживання нею важких і кризових ситуацій, активізацію і нарощування іiі адаптаційних ресурсів. Такими ресурсами можуть бути соціальні якості спільноти, зокрема соціальний капітал (О. А. Ніздрань, Б. Сміт, П. М. Шихірев) та іiі соціальні ресурси: допомога людей одне одному, відчуття належності до спільноти, колективу, соціальна згуртованість (В. О. Васютинський, К. Marzall, E. Wall), соціальна та психологічна підтримка, (H. I. Кривоконь, D. Terry), яка проявляється не лише у розв'язанні, наприклад, соціальних чи економічних проблем, а й передусім у соціально-психологічному контексті, організації рефлексії, осмисленні, активізації, спрямуванні активності в конструктивне річище. Особливістю соціальних ресурсів спільноти є мобільність їх використання (F. Ellis), що полягає в гнучкості, з якою вони можуть бути використані відповідно до нових чи альтернативних практик адаптації спільноти.

У контексті адаптації до умов і наслідків воєнного конфлікту слід зважати на стійкість щодо зовнішніх впливів як окремої особи, так і різних спільнот і суспільства загалом, їхню пружність, стійкість, які розуміються як динамічний процес індивідуального та колективного реагування на несприятливі обставини, економічну кризу, трагічні події, воєнні конфлікти тощо, як здатність протистояти таким обставинам, опановувати їх та відновлюватися після їх впливу [4, с. 223]. У таких умовах виникає потреба в соціальній та психологічній підтримці, мобілізації колективних ресурсів для підвищення рівня індивідуальної та колективної адаптації, долання труднощів та наслідків травматичних подій. Наукові пошуки щодо віповідних психологічних стратегій адаптації спільноти до умов та наслідків воєнного конфлікту грунтуються також на загальних положеннях про: адаптацію та адаптивні характеристики особистості (Г. О. Балл, Ф. Б. Березін, О. М. Кокун, Л. А. Лєпіхова, О. Г. Мороз, А. А. Налчаджян, С. Т. Посохова, Т. М. Титаренко, А. В. Фурман); адаптацію особи та різних соціальних груп в умовах суспільних трансформацій (Є. І. Головаха, О. А. Донченко, О. М. Лактіонов, В. Ф. Моргун, Н. В. Паніна, О. Г. Солодухова).

Населення України постало перед фактом розв'язання воєнних дій на сході України. Вплив неоголошеної війни на особистість є складним, полігенним; він являє собою результат взаємодії багатьох досі не досліджених чинників. За таких обставин більша частина суспільст- 
ва була вимушена хаотично і безсистемно пристосовуватися до нових умов без будь-якого планування, відповідно до ситуації - тут-і-зараз.

Дослідження проблеми адаптації в умовах суспільних трансформацій (М. О. Шульга, А. В. Камбур, О. Л. Луценко, С. В. Хутка, I. О. Філенко) показують, що в українському суспільстві переважають вимушені адаптації, для яких характерне використання захисних, компенсаторних і деприваційних практик. Вони спрямовані на самозбереження адаптанта - підтримку всіма можливими засобами status quo та пов'язані з обов'язковою зміною способів взаємодії з оточенням, але за умови збереження в цілому старих, традиційних цілей та цінностей.

Вітчизняних психологів завжди цікавило, за яких умов знижується адаптивність людини до кризових ситуацій. I хоча, як зазначає Т. М. Титаренко, вивчалися кризи, з якими стикається кожна людина в мирний час, усе ж загальні тенденції залишаються спільними і під час війни. Насамперед зростає кількість деструктивних інтерпретацій ситуації, тимчасово втрачається вміння адекватно реагувати на невдачі і втрати, слабнуть механізми саморегуляції [5, с. 6]. Суспільні трансформації, впливаючи на соціальну ситуацію, породжують процес ціннісного відчуження, який виникає внаслідок усвідомлення особистістю невідповідності офіційно задекларованих цінностей реальним ціннісним орієнтирам. Унаслідок цього відбувається порушення усталених адаптаційних практик, різні групи людей змушені звертатися до стратегії заміщення цінностей, які втратили свою функціональність, інших ціннісних зразків, що більше відповідають новим соціальним умовам.

Коли йдеться про дослідження стратегій адаптації спільноти до наслідків воєнного конфлікту, важливим для нас $є$ розуміння адаптації в складних життєвих ситуаціях як результату оволодіння цією реальністю. Цей результат полягає в позитивних змінах на рівні особистості, групи, соціуму (В. О. Климчук, О. В. Нестерова, R. Tedeschi, L. Calhoun, M. Seligman). Адже криза, з одного боку, може негативно позначитися на умовах життя людини, а $з$ другого - спонукати ії до мобілізації прихованих можливостей та пошуку нових, утілення нереалізованого потенціалу та прихованих ресурсів як особи, так і спільноти, вироблення ефективних психологічних стратегій адаптації і таким чином сприяти позитивним змінам у різних сферах життєдіяльності.

У цьому контексті адаптацію можна розглядати як процес "позитивної адаптаціі” чи “посттравматичного зростання” (R. Tedeschi, L. Calhoun) особи в складних життєвих ситуаціях. Дослідники зазначають, що позитивна адаптація - це не просто результат травматичних подій, а результат оволодіння цією реальністю [6]. Аналізуючи сучасне 
розуміння посттравматичного зростання та його виміри, В. О. Климчук зазначає, що, попри використання різних термінів для позначення цього феномена, усі вони мали спільний “знаменник" - позитивний погляд на людину, яка пережила травму [7, с. 47]. Отже, основна ідея моделі посттравматичного зростання полягає в тому, що людина може використовувати стресову ситуацію як можливість для подальшого розвитку, досягнення більш високого рівня функціонування в певних cферах.

Теоретичний аналіз підходів до проблеми адаптації (Г. О. Балл, А. А. Налчаджян, М. В. Ромм, Т. М. Титаренко та ін.) показав, що в соціально-психологічному контексті явище адаптації - це складний процес. Його слід розуміти не просто як взаємне пристосування суб'єкта адаптації і середовища, а як об'єднання їх у новій системі більш високого рівня організації, яка виникає в результаті активної взаємодії суб'єкта адаптації і середовища й передбачає взаємні двосторонні зміни. Ідеться про активне використання суб'єктом адаптації стратегій і способів оволодіння ситуацією, у який свій внесок роблять як особа, так і інший (індивідуальний чи груповий) суб'єкт, які взаємно адаптуються і творять єдиний адаптивний простір. Отож маємо підстави визначити адаптацію спільноти до умов і наслідків воєнного конфлікту як складний, багатомірний процес взаємодії суб'єкта адаптації (спільноти/особи як члена спільноти) і середовища, яке змінюється під впливом воєнного конфлікту, що передбачає трансформацію системних властивостей спільноти (життєстійкість, психологічна пружність, групова ефективність, рефлексивність тощо), набуття нових засобів побудови продуктивних систем взаємодії, вироблення і застосування відповідних психологічних стратегій адаптації.

Системні властивості спільноти мають різний рівень розвитку на різних етапах соціально-психологічної адаптації та розуміються як здатність цієї спільноти до побудови продуктивних систем взаємодії. Така здатність проявляється в стратегіях поведінки, які використовує спільнота в процесі адаптації до нових умов, зокрема до умов і наслідків воєнного конфлікту. В процесі адаптації спільноти до таких кризових умов активізуються іï когнітивні зусилля (орієнтація в нових умовах, зміни оцінювальних конструктів, долання когнітивних дисонансів, пошук смислу події), активізуються процеси саморегуляції (долання спротивів, усвідомлення змін у власному становищі та в ситуації тощо), актуалізуються нові поведінкові патерни, практики, стратегії відповідно до змінених умов.

Аналіз об'єктивних та суб'єктивних критеріїв адаптації (I. І. Галецька, Г. Ю. Домбровська, М. В. Ромм, В. О. Ядов) дає підстави вважати, що при вивченні психологічних стратегій адаптації спіль- 
ноти особливого значення набувають суб'єктивні критерії (задоволеність соціальним оточенням, роллю, статусом, рівнем самореалізації, основними видами діяльності, реалізацією основних потреб; відчуття соціальної інтегрованості; самооцінка стану здоров'я та адаптивності). Слід зазначити, що, як і суб'єктивне благополуччя, процес адаптації до умов і наслідків воєнного конфлікту може бути розглянутий з позиції суб'єктивної оцінки населенням процесу адаптації, життєздійснення та ступеня особистої адаптованості до таких умов, задоволення базових життєвих потреб. Саме суб'єктивна оцінка населенням особистої адаптованості, як свідчать соціологічні дослідження, є одним із показників адаптаційного потенціалу [2, с. 50].

У своїх наукових пошуках ми спираємося також на положення про адаптацію як вибір альтернативних стратегій поведінки в таких ситуаціях чи умовах, які вимагають зміни взірців, способів поведінки й оцінки зовнішніх подій, та положення про критерії визначення цих стратегій (О. В. Вітенберг, Р. Лазарус, В.В.Москаленко, О. Г. Посипанов, М. В. Ромм, Т. І. Ронгінська та ін.). Стратегії соціальної адаптації дослідники визначають як спосіб дій, лінію поведінки особи, які вона обирає, щоб пристосуватися до змін, що відбуваються довкола. Наразі стратегії соціальної адаптації особи коригуються зовнішніми оцінками соціального оточення та внутрішнім розумінням нею власної ідентичності, яка постає в ролі індивідуального та соціального орієнтира при інтерпретації різноманітних соціальних ситуацій у процесі адаптації. 3 огляду на результати теоретичного аналізу проблеми вивчення стратегій адаптації можемо, зокрема, говорити про чотири основні типи стратегій адаптації: активно-позитивну, активно-негативну, пасивно-позитивну, пасивно-негативну - у разі використання таких ознак, як ступінь соціальної активності членів спільноти та задоволеність із різних сфер своєї життєдіяльності.

Зазначимо, що внаслідок воєнного конфлікту змінюється спосіб життя спільноти і характер соціальної взаємодії як у самій спільноті, так і між різними спільнотами та формуються різні моделі іiї адаптації (пасивні та активні). Засобами їх реалізації виступають психологічні стратегії адаптації, які на рівні спільноти можуть актуалізуватися в процесі зміцнення громадського здоров'я, ціннісного порозуміння, розв'язання проблем внутрішньої міграції, опрацювання травматичного досвіду, застосування медіапрактик, родинної взаємодії, трансформації соціального капіталу.

Відповідно до цих моделей було визначено емпіричні індикатори дослідження стратегій адаптації спільноти: працевлаштування, участь у соціальному і культурному житті регіону переселення, матеріальний добробут, психологічне благополуччя, задоволеність міжосо- 
бовими стосунками; зміцнення громадського здоров'я (самооцінка стану здоров’я, адаптованості, відчуття когеренції, психологічне благополуччя, ставлення до майбутнього, локус контролю, посттравматичне зростання, копінг-стратегії, самоефективність, толерантність, довіра, соціальна активність, згуртованість та соціальна підтримка); встановлення зв'язку 3 витраченим часом на застосування медіапрактик членами спільноти і їх провідним видом; наявність непорозумінь у сім'ї до початку воєнного конфлікту, ступінь спорідненості родинних зв’язків, переструктурування ідентифікаційної матриці, ціннісне порозуміння, соціально-психологічне благополуччя сім’ї, ступінь залученості окремих членів родини до воєнних дій, наявність підтримки 3 боку інших членів родини, особистісні риси.

За найефективніші визнано такі методи вимірювання відповідних характеристик: опитування (анкетування, бесіди, інтерв'ю), особистісні питальники, психосемантичні методи, контент-аналіз, експертна оцінка, самооцінка.

Висновки. Теоретичний аналіз проблеми дослідження, застосування та переінтерпретація відповідних теоретичних положень в контексті адаптації спільноти до умов і наслідків воєнного конфлікту дають змогу сформулювати принципи аналізу адаптації спільноти: розгляд їі на двох рівнях функціонування спільноти - як структурної одиниці суспільства і як значущого середовища життєдіяльності особи, зумовленість змістом суспільних трансформацій, розуміння іiі як вибору альтернативних стратегій поведінки.

Адаптацію спільноти до умов і наслідків воєнного конфлікту визначено як складний, багатомірний процес взаємодії суб'єкта адаптації і середовища, яке змінюється під впливом воєнного конфлікту, що передбачає трансформацію системних властивостей спільноти, активне освоєння нових соціальних умов, набуття засобів побудови продуктивних систем взаємодії, вироблення і застосування психологічних стратегій адаптації. Психологічні стратегії адаптації спільноти запропоновано розглянути на основі моделей: зміцнення громадського здоров’я, ціннісного порозуміння, розв'язання проблем внутрішньої міграції, опрацювання травматичного досвіду, застосування медіапрактик, родинної взаємодії, трансформації соціального капіталу.

Перспективи подальших досліджень вбачаємо в розкритті змісту психологічних стратегій адаптації спільноти, розробленні соціально-психологічних засобів активізації конструктивних стратегій адаптації спільноти й подолання негативних наслідків деструктивних стратегій, експериментальному підтвердженні їх ефективності в підвищенні рівня індивідуальної та колективної адаптації до умов і наслідків воєнного конфлікту. 


\section{Лimepamypa}

1. Штомпка П. Социальное изменение как травма / Петр Штомпка // Социологические исследования. - 2001. - № 1. - С. 6-16.

2. Криза в Україні: зони ураження. Погляд соціологів. - К. : Друк. "Бізнесполіграф", 2010. - 116 с.

3. Васютинський В. Психологічні виміри спільноти: монографія / Вадим Васютинський. - К. : Золоті ворота, 2010. - 120 с.

4. Здоров'я 2020: Основи європейської політики та стратегія для XXI століття. - Копенгаген : Європ. регіон. бюро ВООЗ, 2013. - 224 с.

5. Титаренко Т. М. Напрями психологічної реабілітації особистості, що переживає події війни / Т. М. Титаренко // Психологічна допомога особистості, що переживає наслідки травматичних подій : зб. статей / Ін-т соц. та політ. психології ; Пред-во Польської акад. наук у м. Києві ; Соц.-психол. метод. реабіліт. центр. - К. : Міленіум, 2015. - 150 с. - С. 3-13.

6. Tedeschi R. G. Posttraumatic growth: conceptual foundations and empirical evidence / Tedeschi R. G., Calhoun L. G. // Psychological Inquiry. - 2004. Vol. 15. - № 1. - P. 1-18.

7. Климчук В. О. Посттравматичне зростання та як можна йому сприяти у психотерапії / В. О. Климчук // Наука і освіта. - 2016. - № 5. - С. 46-52.

\section{References}

1. Shtompka, P. (2001). Sotsialnoye izmeneniye kak travma [Social change as a trauma]. Sotsiologicheskiye issledovaniya [Sociological Studies], 1, 6-16 (rus).

2. Kryza v Ukraini: zony urazhennia. Pohliad sotsiolohiv (2010). [Crisis in Ukraine: zone of defeat. View of sociologists]. Kyiv: Biznespoligraf Publ. (ukr).

3. Vasiutynskyi, V. O. (2010). Psykholohichni vymiry spilnoty [The psychological measuruments of community]. Kyiv: Zoloti vorota Publ. (ukr).

4. Zdorovia-2020: Osnovy yevropeiskoi polityky ta strategiia dlia XXI stolittia (2013). [Health-2020: Basics of European policy and strategy for the 21-st century]. Kopenhagen: WHO Regional Office for Europe (ukr).

5. Tytarenko, T. M. (2015). Napriamky psykholohichnoi reabilitatsii osobystosti, shcho perezhyvaie podii viiny [Directions of psychological rehabilitation of personality who experiences the war events]. Psykholohichna dopomoha osobystosti, shcho perezhyvaie naslidky travmatychnykh podii [Psychological support of personality who experiences the consequences of traumatic events] (pp. 3-13). Kyiv: Milenium Publ. (ukr).

6. Tedeschi, R. G. and Calhoun, L. G. (2004.) Posttraumatic growth: conceptual foundations and empirical evidence. Psychological Inquiry, 15 (1), 1-18.

7. Klymchuk, V. O. (2016). Posttravmatychne zrostannia ta yak mozhna yomu spryiaty u psykhoterapii [Posttraumatic growth and ways of facilitating it in psychotherapy]. Nauka i osvita [Science and education], 5 (16), 46-52 (ukr). 


\section{Korobka L. M. Community in conditions of war conflict: theoretical basics of the research of psychological adaptation strategies}

The article deals with the theoretical grounds analysis of psychological adaptation strategies of communities to conditions and consequences of war conflict which were based on the concept of social trauma by P. Shtompka were formulated: its consideration on two levels of community functioning - as a structural unit of society and as a meaningful habitat of person's livelihood; stipulation by content of social transformation; understanding it as a choice of alternative strategies of behavior. The community adaptation to the conditions and consequences of military conflictt is described as a complex multidimensional process of interaction between the subject of adaptation and the environment which changes under the influence of military conflict that allows for the transformation of the system properties of community, active development of new social conditions, acquisition of means for making productive system of interaction, development and application of the adaptation's psychological strategies. The objective and subjective criteria of community adaptation were separated. The importance of subjective criteria was shown: satisfaction of the various components of life, feeling social support, feeling social integration, subjective well-being, self-esteem of health and adaptability. The strategies of psychological adaptation were proposed to consider on basis of the models: strengthening community health, understanding on values, solving the problems of internal migration, processing the traumatic experience, application of mediapractices, family interaction, transformation of social capital. According these models the indicators of the research were defined.

Key words: community, adaptation, conditions of war conflict, indicators of adaptation, psychological adaptation strategies, indicators of research of communities' adaptation strategies.

(C) Коробка Л. М. 